\title{
Studies on Performance of French Bean (Phaseolus vulgaris L.) cv. Contender for Seed Production under Garhwal Himalayas
}

\author{
Jitendra Meena ${ }^{1}$, B.P. Chamola ${ }^{2}$, D.K. $\operatorname{Rana}^{1}$ and K.K. Singh ${ }^{3 *}$ \\ ${ }^{1}$ Department of Horticulture, ${ }^{2}$ Department of Forestry, H.N.B. Garhwal University, \\ Srinagar-246174, Uttarakhand, India \\ ${ }^{3}$ Department of Agriculture, Career Point University, Kota, Rajasthan, India \\ *Corresponding author
}

\section{Keywords \\ Rhizobium, \\ NPK, \\ Humic acid, Seed \\ production and \\ quality, Yield}

Article Info

Accepted:

07 January 2018

Available Online:

10 February 2018

\section{A B S T R A C T}

The present investigation was carried out during 2014-15 in Department of Horticulture, H.N.B. Garhwal University, Srinagar (Garhwal) with the sole objective to find out the effect of integrated nutrient management on quality seed production of French bean genotype. Aim of the study is to observe the effect of different combinations of organic sources of nutrients viz., FYM, NPK, along with bio-fertilizer on different growth parameters, yield and profitability of French bean cultivar Contender. The experiment was laid out in Randomized Block Design with eleven treatments and three replications. In this investigation, the results revealed that application of $100 \%$ RDF + Rhizobium culture+ Humic Acid. significantly decrease the days of germination (9.33), growth parameters and yield of the crop viz., plant height $(43.50 \mathrm{~cm}$ after 60 days of sowing), number of branches plant $^{-1}$ (3.83 after 60 days of sowing), green pod Weight $(6.87 \mathrm{gm})$, green pod number plant $^{-1}(67)$, number of grain pod $^{-1}(6.07)$, Seed Yield Plant ${ }^{-1}$ (38.17 gm), seed yield bed ${ }^{-1}$ $(1.027 \mathrm{~kg})$ and seed yield $\mathrm{hq}^{-1}(1430.083 \mathrm{~kg})$. For overall point of view of the outcome of the experiment it has been reveal that genotype with relatively bolder seeds with more number of seeds per pod, and higher bearing capacity per plant generally gives higher seed yield and relatively good plant vigour. Treatment T8, T9 and T10 is suitable for considering once for seed production point of view.

\section{Introduction}

Seed is considered as the basic critical and vital input for enhancing and stabilizing productivity of different vegetable crops, harnessing higher net monitory returns per unit area, input and time of different vegetable crops. Good seed therefore, is the basis or critical input upon which all other inputs will depend for their full effectiveness. According to Food and Agricultural Organization (FAO) of United Nations, India is the world leader in production of dry seed of French bean followed by Brazil and Myanmar. On the other hand China is world leader in production of green beans followed by Indonesia and then Turkey (FAOSTAT, 2010). Scarcity of quality seed is one of the major hinders faced by the French bean growers of the Hills of Uttarakhand for producing quality French bean pod. Although there is greater scope for seed production of French bean during winter 
season in the Hills of Uttarakhand. Genotype is the most important factor in any crop production program and is the basic material to which all other technologies are applied (Goutam et al., 2001). Therefore, unless a good genotype of high potential is used; other technologies will also not work. These genotypes are also greatly varied in their performance under different agro-climatic conditions of the country which often creates confusions among the farmers about their choice of variety. So, selection of particular variety for seed production is also prime important for higher seed yield. Hence, it is essential to look forward for the production of quality seed in the state itself to uplift quality production of French bean. In this back drop, the present experiment was undertaken with the objectives to study the performance of French bean genotypes for seed yield and its varietal characterization based on plant morphology.

\section{Materials and Methods}

This present experiment was conducted at Department of Horticulture, Horticulture Research Centre, Chauras H.N.B. Garhwal central University, Srinagar, Uttarakhand India, during 2014/2015. The soil of experiment site is sandy loam in nature with around $0.57 \%$ organic carbon, $0.06 \%$ total nitrogen, available Phosphorous $30.10 \mathrm{~kg} / \mathrm{ha}$, available Potassium $115.7 \mathrm{~kg} / \mathrm{ha}$ and $\mathrm{pH}$ 6.5. The experimental site is under subtropical humid region with range of average temperature of $12^{\circ} \mathrm{C}$ to $36^{\circ} \mathrm{C}$ during the experimental period (September to February). Eleven treatment used for evaluated to assess growth, flowering and yield attributing characters of plants and seed and quality parameters of seed to screen out for best performing genotype for seed production purposes. Preliminary information on eleven treatments is given in Table 1. The experiment was laid out in Randomized Block Design with 3 replications of each treatment. French bean seeds were sown in the field at a spacing of $60 \mathrm{~cm} \times 30 \mathrm{~cm}$ in plots of $3 \times 2 \mathrm{~m}^{2}$ size.

\section{Results and Discussion}

\section{Growth and flowering characters}

The representation of mean data of various growth and flowering characters of French bean variety in Table 2 are showing significant variations.

With respect to plant height the highest value was obtained in case of the treatment $\mathrm{T} 8$ $(100 \%$ RDF+ Rhizobium culture + Humic Acid) $(43.50 \mathrm{~cm})$ and lowest for the treatment T0 (control) $(26.33 \mathrm{~cm})$ considering the number of branches per plant was recorded as the highest for the treatment $\mathrm{T} 8(3.83 \mathrm{~cm})$ and lowest in case of treatment T0 $(3.03 \mathrm{~cm})$. Leaf area $\left(\mathrm{cm}^{2}\right)$ per plant counted as maximum for the treatment T8 $(8.33 \mathrm{~cm})$ and minimum for the treatment $\mathrm{T} 0(5.93 \mathrm{~cm})$ from the results and discussion of these plant growth parameters it can be concluded that under the agro-climatic condition of the experimental site in general, a good plant vigour has been shown in Treatment T8, T9 and T10 respectively. Whereas comparatively poor plant vigour specified in treatment T0 and T1. The differences in the plant growth characters may be due to the genetic variability within the genotype itself or may be due to the environmental effects. Amongst the treatments in case of days taken to flowering sowing to first flowering Observed in treatment $\mathrm{T} 8$ (41.67), T9 (46.33) and T3 (47.00). They differed statistically significantly from other genotype and can be considered as early flowering once. Whereas the longest duration for first flowering has been recorded In treatment $\mathrm{T} 0, \mathrm{~T} 1$ and $\mathrm{T} 10$ (52, 50 and 50 days respectively). These can be considered as late flowering treatments. Similar findings with respect to days taken to pod set from $50 \%$ 
flowering in common bean has been reported by Kamaluddin and Shahid- Ahmed (2011).

\section{Yield attributing characters}

The data pertaining to yield attributing characters are presented in Table 3. Yield attributing characters were affected significantly within treatment. Pod weight differed in a considerable manner among the treatments which was maximum in T8, T9 and $\mathrm{T} 10$ (6.87, 6.12, and $6.00 \mathrm{gm}$ respectively) whereas minimum pod weight was observed in treatment $\mathrm{T} 1$ (3.80), $\mathrm{T} 7$ (4.47) and T5 (4.63)gm. The genotype included in the study produced an average variation of number of pods per plant was 36.67 to 67.00 . Among the treatment $\mathrm{T} 8$ produced maximum number of pods per plant (67.00) followed by T9 (62.33) and T10 (60.33). Mature pod yield obtained the highest in the treatment T8 (343.00 g/plant) followed by $\mathrm{T} 9$ (33.93 g/plant) and T10 (295.00). The lowest mature pod yield obtained from Treatment T0 (148.00 g/plant). The highest number of grain per pod was observed in treatment T8 (6.07), T9 (5.93) and T10 (4.93) - whereas minimum number of grain per pod was observed in treatment T0 and $\mathrm{T} 1(3.27$ and 3.80). The results are corroborated with the finding of Shukla et al., (2006) their finding revealed that number of pods per plant had a positive contribution to seed yield.

Table.1 Preliminary information on eleven treatments

\begin{tabular}{|l|c|}
\hline RDF(NPK) & $\mathrm{T}_{1}$ \\
\hline $100 \%$ RDF+ Rhizobium culture & $\mathrm{T}_{2}$ \\
\hline $100 \%$ RDF+ Humic Acid & $\mathrm{T}_{3}$ \\
\hline $75 \%$ RDF+ Rhizobium culture & $\mathrm{T}_{4}$ \\
\hline $75 \%$ RDF+ Humic Acid & $\mathrm{T}_{5}$ \\
\hline $50 \%$ RDF+ Rhizobium culture & $\mathrm{T}_{6}$ \\
\hline $50 \%$ RDF+ Humic Acid & $\mathrm{T}_{7}$ \\
\hline $100 \%$ RDF+ Rhizobium culture +Humic Acid & $\mathrm{T}_{8}$ \\
\hline $75 \%$ RDF+ Rhizobium culture + Humic Acid & $\mathrm{T}_{9}$ \\
\hline 50\% RDF+ Rhizobium culture + Humic Acid & $\mathrm{T}_{10}$ \\
\hline Control & $\mathrm{T}_{0}$ \\
\hline
\end{tabular}

Normal cultural practices were followed and plant protection measures. Particularly against while fly, were taken by spraying Hamla 550 [Choloropyriphos + cypermethrin $(50 \%+50 \%)$ E.C.] The mentioned chemical was spread in two times at 10 days interval during the cultivation process. Pooled mean values of the parameters in each replication were statistically analyzed following Randomized Block Design. The 'Table' formulated by fisher and Yates (1963) were consulted for the purpose of comparison of ' $F$ ' values and for determination of critical differences (C.D. values) at the probability of 0.05 . 
Table.2 Performance of different treatment for growth and flowering characters

\begin{tabular}{|l|c|c|c|c|c|}
\hline Treatment & $\begin{array}{c}\text { Plant height } \\
\text { (cm) }\end{array}$ & $\begin{array}{c}\text { Number of } \\
\text { branch/plant }\end{array}$ & $\begin{array}{c}\text { Days to 50\% } \\
\text { Flowering }\end{array}$ & $\begin{array}{c}\text { Days to } \\
\text { germination }\end{array}$ & $\begin{array}{c}\text { Leaf } \\
\text { area(cm }\end{array}$ \\
\hline $\mathbf{T}_{\mathbf{1}}$ & 28.98 & 2.93 & 50.00 & 9.33 & 6.40 \\
\hline $\mathbf{T}_{\mathbf{2}}$ & 30.96 & 3.00 & 48.00 & 10.00 & 7.13 \\
\hline $\mathbf{T}_{\mathbf{3}}$ & 30.05 & 3.03 & 47.00 & 12.33 & 7.10 \\
\hline $\mathbf{T}_{\mathbf{4}}$ & 33.50 & 3.23 & 48.67 & 11.67 & 7.00 \\
\hline $\mathbf{T}_{\mathbf{5}}$ & 29.05 & 2.77 & 48.33 & 12.67 & 6.97 \\
\hline $\mathbf{T}_{\mathbf{6}}$ & 33.67 & 2.97 & 49.33 & 12.67 & 6.70 \\
\hline $\mathbf{T}_{\mathbf{7}}$ & 27.72 & 3.03 & 49.67 & 11.67 & 6.60 \\
\hline $\mathbf{T}_{\mathbf{8}}$ & 43.50 & 3.83 & 41.67 & 9.33 & 8.33 \\
\hline $\mathbf{T}_{\mathbf{9}}$ & 39.00 & 2.97 & 46.33 & 10.33 & 7.90 \\
\hline $\mathbf{T}_{\mathbf{1 0}}$ & 34.25 & 2.33 & 50.00 & 11.33 & 7.80 \\
\hline $\mathbf{T}_{\mathbf{0}}$ & 26.33 & 2.13 & 52.00 & 12.67 & 5.93 \\
\hline $\mathbf{R a n g}_{\mathbf{C}}$ & $\mathbf{2 6 . 3 3 - 4 3 . 5 0}$ & $\mathbf{2 . 1 3 - 3 . 8 3}$ & $\mathbf{4 1 . 6 7 - 5 2 . 0 0}$ & $\mathbf{9 . 3 3 - 1 2 . 6 7}$ & $\mathbf{5 . 9 3 - 8 . 3 3}$ \\
\hline $\mathbf{C D}_{\mathbf{5}} \mathbf{5}$ & $\mathbf{4 . 1 0}$ & $\mathbf{0 . 4 0}$ & $\mathbf{5 . 2 5}$ & $\mathbf{2 . 8 0}$ & $\mathbf{1 . 1 5}$ \\
\hline
\end{tabular}

Table.3 Performance of different treatment for yield attributing characters cv. Contender

\begin{tabular}{|c|c|c|c|c|c|c|c|c|}
\hline Treatment & $\begin{array}{l}\text { Pod } \\
\text { Weight } \\
\text { (gm) }\end{array}$ & $\begin{array}{l}\text { No. of } \\
\text { pod/plant }\end{array}$ & $\begin{array}{l}\text { Pod yield } \\
\text { /plant } \\
\text { (gm) }\end{array}$ & $\begin{array}{l}\text { Number } \\
\text { of grains/ } \\
\text { pod }\end{array}$ & $\begin{array}{l}\text { Seed } \\
\text { length } \\
(\mathrm{cm})\end{array}$ & $\begin{array}{l}\text { Seed yield/ } \\
\text { Plant (gm) }\end{array}$ & $\begin{array}{l}\text { Seed } \\
\text { yield/ } \\
\text { bed }(\mathbf{k g})\end{array}$ & $\begin{array}{l}\text { Seed } \\
\text { yield/hq } \\
(\mathrm{kg})\end{array}$ \\
\hline $\mathbf{T}_{1}$ & 3.80 & 44.67 & 188.33 & 3.80 & 1.18 & 14.40 & 0.370 & 463.560 \\
\hline $\mathbf{T}_{2}$ & 5.05 & 51.00 & 261.67 & 4.93 & 1.38 & 27.97 & 0.533 & 742.610 \\
\hline $\mathbf{T}_{3}$ & 4.78 & 51.67 & 240.00 & 3.87 & 1.32 & 23.22 & 0.468 & 652.103 \\
\hline $\mathbf{T}_{4}$ & 5.00 & 49.00 & 251.67 & 4.40 & 1.33 & 21.08 & 0.415 & 577.841 \\
\hline $\mathbf{T}_{5}$ & 4.63 & 50.00 & 226.67 & 4.27 & 1.33 & 20.83 & 0.291 & 596.407 \\
\hline$T_{6}$ & 4.80 & 49.00 & 226.67 & 4.57 & 1.25 & 21.57 & 0.445 & 619.615 \\
\hline $\mathbf{T}_{7}$ & 4.47 & 50.33 & 216.67 & 3.88 & 1.23 & 19.67 & 0.403 & 561.597 \\
\hline $\mathbf{T}_{8}$ & 6.87 & 67.00 & 343.00 & 6.07 & 1.53 & 38.17 & 1.027 & 1430.083 \\
\hline $\mathbf{T}_{9}$ & 6.12 & 62.33 & 339.93 & 5.93 & 1.43 & 36.10 & 0.823 & 1146.680 \\
\hline $\mathbf{T}_{10}$ & 6.00 & 60.33 & 295.00 & 4.87 & 1.45 & 30.55 & 0.662 & 922.227 \\
\hline $\mathbf{T}_{0}$ & 4.80 & 36.67 & 148.33 & 3.27 & 1.08 & 10.80 & 0.265 & 368.980 \\
\hline Range & $\begin{array}{l}3.80- \\
6.87\end{array}$ & $\begin{array}{l}36.67- \\
67.00\end{array}$ & $\begin{array}{c}148.33 \text { - } \\
343.00\end{array}$ & $\begin{array}{l}3.27- \\
6.07\end{array}$ & $\begin{array}{l}1.08- \\
1.53\end{array}$ & $\begin{array}{l}\text { 10.80- } \\
38.17\end{array}$ & $\begin{array}{c}0.265- \\
1.027\end{array}$ & $\begin{array}{c}\text { 368.98- } \\
1430.083\end{array}$ \\
\hline CD 5\% & 0.70 & 8.10 & 40.50 & 0.36 & 0.22 & 3.20 & 90.25 & 180.20 \\
\hline
\end{tabular}

The treatment produced longest seed length was T8 (1.53), T9 (1.43), T0 (1.45) whereas the minimum seed length was observed in Treatment T0 and T1 $(1.08$ and $1.18 \mathrm{~cm})$. So, they can be considered as bolder seeded genotype. Genotype with lowest seed length was observed in treatment $\mathrm{T} 0$ and $\mathrm{T} 1$. So, they can be considered as lighter seeded genotype The genotypic differences on seed length in pole type French bean have also 
been reported by Pandey et al., (2011). 100 seed weight showed direct positive correlation with the seed size. These results are in consensus with the findings of Coimbra et al., (1998) in French bean. As per as seed yield is concerned the highest seed yield/plant, per bed and per hectare was obtained from treatment T8 $(38.17 \mathrm{gm} 1.027 \mathrm{~kg}$ and $1430.083 \mathrm{~kg}$ ) respectively followed by Treatment T9 $(36.0 \mathrm{~g}, 0.823 \mathrm{~kg}$ and 1146.680 $\mathrm{kg}$ respectively) and lowest result in this respect was observed in Treatment T0 (10.80gm, $0.265 \mathrm{~kg}$ and $368.98 \mathrm{~kg}$ respectively). Relatively good seed yield has been observed in Treatment T8 (100\% RDF+ Rhizobium culture + Humic Acid) and T9 $(75 \%$ RDF + Rhizobium culture + Humic Acid). Whereas lesser seed yield was observed in Treatment T0 (Control). Seed quality parameters: Seed quality parameters amongst the genotypes (Table 3) clearly indicated that there were significant differences present among the Treatments under study.

Germination percentage of the harvested seed was measured highest for the Treatment T8 and T9 lowest for the Treatment T0.minimum days of germination was observed in treatment $\mathrm{T} 8$ whereas maximum days of germination was observed in treatment T0 Similar findings have been revealed by Chaudhury et al., (2004) in the experiment with different French bean genotypes.

In conclusion, from overall point of view of the results and discussion it can be concluded that seeds obtained from Treatment $\mathrm{T} 8$ with relatively bolder seeds with more number of seeds per pod, and higher bearing capacity per plant generally gives higher seed yield. Among them, Treatment T8 (100\% RDF+ Rhizobium culture +Humic Acid) and T9 (75\% RDF+ Rhizobium culture +Humic Acid) was the best one as it produced highest seed yield and relatively good plant vigour.
This may be due to the fact that the agroclimatic condition of the experimental side during the cropping season best suited for this genotype. Among the other Treatment T9 and T10 also can be considered promising once for seed production point of view. Here from, it may be pointed out that while initiating the seed production programmed as a commercially lucrative venture for French bean mostly in the Subtropical condition of Uttarakhand Hills, one may consider variety like contender as the most promising once due their relatively good plant vigour and high seed yield potentiality.

\section{References}

Chaudhury, K., Sannigrahi, A.K. and Singh, B. 2004. Varietal evaluation of French bean for Assam plains, Environment and Ecology. 17(1): 236-237.

Coimbra, J.L.M., Guidolin, A.F., Carvalho, F.I.F. De. And Duarte, I.A. 1998. Quantitative analysis of genetic and phenotypic parameters in bean (Phaseolus vulgaris L.) Pesquisa Agropecuaria Gaucha 4(2): 157-165.

FAOSTAT. 2010. Data Food and Agricultural Organization (FAO) of United Nations. htm.

Fisher, R. and Yates, F. 1963. Statistical table for biological, agricultural and medical researchers, 6th edn. Olivertion (FAO) of United Nations. htm.

Fisher, R. and Yates, F. 1963. Statistical table for biological, agricultural and medical researchers, 6th cal, agricultural and medical researchers, 6th and Boyd Ltd., London. 146p.

Goutam, P., Mulani, S. and Arvind, G. 2001. Evaluation of Genetic Diversity in Some pea varieties Grown in North-Eastern hills. Indian Journal of Hill Farming, 6(2): 2728.

Kamaluddin, S. and Shahid, A. 2011. Variability, Correlation and path analysis 
for seed yield and yield related traits in common beans. Indian Journal of Horticulture, 68(1): 56-60.

Pandey, Y.R., Gautam, D.M., Thapa, R.B., Sharm, M.D. and Paudya, K.P. 2011. Evaluation of pole-type French bean genotypes in the mid hills of western Nepal. Journal of Nepal Agriculture
Research, pp.80-86.

Shukla, S.K., Mahajan, V., Majumdar, N.D., Tiwari, V., Prasad, S.V.S. and Gupta, H.S. 2006. Evaluation of rajmah (Phaseolus vulgaris L.) genotypes in mid-altitudes North-West Himalayas. Indian Journal of Genetics and Plant Breeding, 66(4): 345346.

\section{How to cite this article:}

Jitendra Meena, B.P. Chamola, D.K. Rana and Singh, K.K. 2018. Studies on Performance of French Bean (Phaseolus vulgaris L.) cv. Contender for Seed Production under Garhwal Himalayas. Int.J.Curr.Microbiol.App.Sci. 7(02): 676-681.

doi: https://doi.org/10.20546/ijcmas.2018.702.084 